\author{
Aleksandra Kremer \\ Harvard University \\ akremer@fas.harvard.edu
}

\title{
Przekłady, kanony, przemieszczenia
}

\section{Translations, Canons, Displacements}

Abstract: The aim of the article is to open up a discussion of Justin Quinn's book Between Two Fires: Transnationalism and Cold War Poetry. The monograph focuses on transnational movements of poetry between Czech culture and the Anglophone world during the Cold War. The book allows us to reconsider the way in which we study similar transfers of Polish literature and the categories and models we use to describe them, which usually stem from translation studies, studies of reception of Polish literature abroad, and recent debates on world literature.

Keywords: world literature, translation, transnationalism, canon, Cold War

Streszczenie: Artykuł stanowi zachętę do podjęcia dyskusji z książką Justina Quinna Betwen Two Fires: Transnationalism and Cold War Poetry. Monografia ta opisuje transnarodowe wymiany literackie zachodzące między kulturą czeską a krajami anglojęzycznymi w czasach zimnej wojny. Książka Quinna pozwala nam przemyśleć, w jaki sposób badamy podobne transfery literatury polskiej oraz stosowane zwykle w takich sytuacjach modele i ujęcia, związane często z przekładoznawstwem, studiami nad recepcją literatury polskiej za granicą czy dyskusjami na temat literatury światowej.

Słowa kluczowe: literatura światowa, przekład, transnacjonalizm, kanon, zimna wojna

W swojej najnowszej książce Between Two Fires: Transnationalism and Cold War Poetry ${ }^{1}$ Justin Quinn przypomina pokrótce rozliczne dyskusje, które toczyły się w ostatnich latach na temat literatury światowej. Przykładowo Pascale

1 Dosłownie: Między dwoma ogniami. Transnacjonalizm a poezja zimnej wojny. „Between two fires" jest idiomem oznaczającym atak z obu stron, bycie między młotem a kowadłem. Jednocześnie tytuł książki zawiera grę słów - dwa ognie wskazują na dwie strony wojny nazywanej powszechnie „zimną”. J. Quinn, Between Two Fires: Transnationalism and Cold War Poetry, Oxford 2015. 
Casanova opisywała literaturę światową jako pole literackiej rywalizacji, w której uznanie przez wieki zdobywało się w Paryżu, dopóki nowym hegemonem nie stał się w ostatnich dekadach świat angloamerykański. Szerszą wizję literatury światowej proponował z kolei David Damrosch, którego interesowały wszystkie teksty krążące poza kulturą swojego pochodzenia i taki też sposób czytania, zaangażowany w poznanie obcej literatury. Wreszcie Emily Apter, w odpowiedzi na rosnące zainteresowanie tekstami czytanymi w przekładzie, w obcych kontekstach kulturowych, przypomniała o roli nieprzekładalności, o nieprzystawalność terminów i językowych obrazów świata, o pragnieniu posiadania cudzych tekstów, połączonym z niewiedzą na temat odległych kultur².

Ta ostatnia refleksja na temat nieprzekładalności oraz uprzywilejowanej pozycji, z której zachodni uczeni prowadzą swoje badania literatury światowej, zdaje się najlepiej rezonować z przekonaniami polskich badaczy na temat miejsca literatury polskiej w światowym obiegu. Polscy uczeni nieraz ubolewają nad nieobecnością czy nikłą obecnością polskich tekstów literackich i literaturoznawczych zagranica, co wynika zarówno z innych oczekiwań wobec polskiego kanonu, jak i dostępności przekładów. Już Czesław Miłosz, przygotowując amerykańską antologię polskiej poezji powojennej w 1965 roku, wprost przyznawał, że z powodu nieprzekładalności właściwie pominął poezję metryczną; z kolei w swoim amerykańskim podręczniku do historii literatury przypominał, że literatura polska zawsze skłaniała się ku poezji i teatrowi, a nie powieściopisarstwu, przez co pozostała słabo znana w krajach anglojęzycznych. Do dziś dostęp do literatury polskiej XIX i początku XX wieku jest ograniczony przez jakość dawnych angielskich przekładów - lub ich brak ${ }^{3}$.

Choć wspomniana książka Quinna dotyczy tylko czasów zimnej wojny i skupia się na ówczesnych transferach między poezją czeską a poezją anglojęzyczną, to przykłady i sposób rozumowania Quinna są także przydatne dla badaczy literatury polskiej. Cytowane poniżej fragmenty książki mogą zachęcić do przemyślenia analogicznych historii z udziałem literatury polskiej. Co istotne dla tych przemyśleń w pracy Quinna wychodzimy poza refleksję nad przekładem i liczbą dostępnych tłumaczeń, zwracając uwagę na innego rodzaju

2 J. Quinn, dz. cyt., s. 14-20. Polskie wprowadzenie w tematykę literatury światowej, w tym wymienionych książek, stanowi numer 4 „Tekstów Drugich” z 2014 roku, a zwłaszcza artykuł P. Czapliński, Literatura światowa i jej figury, „Teksty Drugie” 2014, nr 4, s. 13-40.

3 Np. A. Nasiłowska, Pole literatury, „Teksty Drugie” 2014, nr 4, s. 10; B. Shallcross, Requiem for a Canon? The Peculiar Case of the Transatlantic Canon [w:] Being Poland: A New History of Polish Literature and Culture since 1918, red. T. Trojanowska, J. Niżyńska, P. Czapliński, z pomocą A. Polakowskiej, Toronto-Buffalo-London 2018, s. 160; B. Johnston, Translated from the Polish: The Fates, Feats, and Foibles of Polish Literature in English [w:] Being Poland, dz. cyt., s. 309, 311; C. Miłosz, Historia literatury polskiej, Kraków 2010, s. 11; Postwar Polish Poetry: An Anthology, red. C. Miłosz, wyd. 3, Berkeley-Los Angeles-London 1983, s. xi-xii. Podobne spojrzenie na światową recepcję polskiej teorii literatury można znaleźć w: D. Ulicka, Przegapiona okazja, „Teksty Drugie” 2018, nr 6. 
przesunięcia, które w tym wypadku zaszły podczas wielorakich dwustronnych wymian pomiędzy kulturą czeską i anglosaską.

W pierwszym rozdziale książki Quinna możemy przeczytać o doświadczeniach samego autora, badacza i poety, który trafił do Czechosłowacji w 1991 roku, zaraz po ukończeniu studiów w Irlandii. Quinn tak przedstawia swoją ówczesną wiedzę na temat kanonu literatury czeskiej:

Przed wyjazdem zacząłem się uczyć czeskiego i poznawać tamtejszą literaturę: Jaroslava Haška, Ivana Klímę, Bohumila Hrabala, Milana Kunderę, a także poezję i eseje Miroslava Holuba. W tamtym czasie Holub był jednym z najlepiej znanych poetów w świecie anglojęzycznym. Rekomendowali go tacy luminarze jak Seamus Heaney i Ted Hughes (Hughes przedstawiał Holuba jako ,jednego z kilku najważniejszych autorów piszących dziś wiersze”). Choć to inny czeski poeta, Jaroslav Seifert, otrzymał literacką Nagrodę Nobla w 1984 roku, nie było on znany poza Czechosłowacją. Razem z Vasko Popą, Tadeuszem Różewiczem, Zbigniewem Herbertem, Czesławem Miłoszem i Josifem Brodskim właśnie Holub należał do najważniejszych nazwisk w poezji anglojęzycznej od lat sześćdziesiątych do dziewięćdziesiątych XX wieku. Jeśli Seifert mógł dostać Nobla, Holub wydawał mi się pewniakiem. Jako poeta cieszący się międzynarodowym uznaniem z pewnością był postacią kluczową dla kultury czeskiej, podobnie jak, powiedzmy, Seamus Heaney w Irlandii. Tak jak nie-Irlandczyk mógłby się sporo nauczyć o Irlandii podczas lektury tomików North czy Door into the Dark, tak i ja miałem niedługo poznać istotę Czechosłowacji poprzez poezję Holuba.

Byłem więc zaskoczony, kiedy w Pradze okazało się, że większość mieszkańców miasta nigdy nie słyszała o Holubie. Zafrapowani wymieniali mi w odpowiedzi kolejne nazwiska poetów czeskich, o których uczono ich w szkole. Z zakłopotaniem odkrywali jednak, że z wyjątkiem Seiferta (którego poezji nie mogłem znaleźć po angielsku) nazwiska tych autorów nic mi nie mówiły. Jeden lekarz faktycznie słyszał o innym lekarzu, który nazywał się Holub i parał się pisaniem, ale niewątpliwie nie był to ktoś, z którego dumne by było całe społeczeństwo, nie wspominając już o tym, by go w ogóle znało ${ }^{4}$.

Jak pokazuje Quinn w tej barwnej opowieści, zaskoczenie, które przeżywał w Pradze, nie wynikało z samej niedostępności przekładów poezji czeskiej na angielski czy z braku dostępu do angielskiego tłumaczenia Seiferta. Zadziwienie brało się głównie z niewspółmiernej roli, jaką Holub odgrywał w świecie anglojęzycznym - w porównaniu z jego statusem w Pradze. Jak pisze dalej w swojej książce Quinn, niewątpliwie „coś stało się” z czeską poezją Holuba, w momencie gdy wkroczyła ona w obręb kultury anglojęzycznej. Co więcej, sprawcą tej zmiany nie były same przekłady, gdyż wiersze Holuba, stosunkowo łatwe do tłumaczenia, nie straciły ani nie zyskały aż tak wiele w nowej

4 J. Quinn, dz. cyt., s. 10-11. Tu i dalej tłumaczenia fragmentów - A.K. 
postaci językowej. Innymi słowy, ich przekładalność na angielski była warunkiem koniecznym, ale niewystarczającym do osiągnięcia uznania wielokrotnie większego niż w Czechosłowacji.

Podobne przykłady zaskakujących przemieszczeń, które wykraczają daleko poza problemy przekładalności, znamy też z historii literatury polskiej. Wiemy na przykład, że nie najlepsze przekłady powieści Witolda Gombrowicza i Stanisława Lema nie zaszkodziły tym twórcom w ich amerykańskiej recepcji - ale wiemy też, że realnie podjęte przez Stanisława Barańczaka prace przekładowe nad poezją Mirona Białoszewskiego nie mogły zostać opublikowane w latach dziewięćdziesiątych, ze względu na brak zgody właściciela praw autorskich. Bill Johnston opisywał różne świadomie podejmowane działania tłumaczy i instytucji, by publikować i promować literaturę polską w USA ${ }^{5}$. Te jednostkowe inicjatywy, wespół z przypadkiem, chcąc nie chcąc doprowadziły do różnych przesunięć pomiędzy krajowym a zagranicznym obiegiem danego utworu. Przykładowo wiemy, że przez wiele lat Jennifer Croft próbowała zainteresować amerykańskich wydawców swoim przekładem Biegunów Olgi Tokarczuk - po publikacji których Tokarczuk bardzo szybko otrzymała Nagrody Bookera i Nobla w 2018 i 2019 roku. Tak się złożyło, że zaraz po Flights ukazała się powieść Prowadź swój plug przez kości umartych, w przekładzie Antonii Lloyd-Jones. Na fali nagród przyznawanych Tokarczuk publikacja ta wzbudziła duży odzew wśród recenzentów, trafiła też na listę dziesięciu najlepszych książek 2019 roku według tygodnika „Time”. Tymczasem wydane po angielsku kilka i kilkanaście lat wcześniej Dom dzienny, dom nocny i Prawiek i inne czasy, książki w swoim czasie chętnie czytane, nagradzane i doceniane w Polsce, $\mathrm{w}$ świecie anglojęzycznym nie zyskały wtedy tak dużego rozgłosu ${ }^{6}$.

Przypadki, dysproporcje i niewspółmierności odgrywają szczególną rolę, gdy mówimy o próbach zaistnienia niewielkiej kultury środkowoeuropejskiej w świecie literatury anglojęzycznej. Tę asymetrię i uprzywilejowanie kulturowe niektórych krajów Zachodu piszących o literaturze światowej podkreślała Emily Apter, zwracając uwagę na nakładanie na obce kultury nieprzystających do nich terminów i periodyzacji. W swojej książce Quinn przypomina nam jednak, że podobne przesunięcia zachodzą również podczas transferów w drugą stronę, gdyż mniejsze kraje równie swobodnie czerpią z zasobów większych kultur. Quinn sam doświadczył tego po przyjeździe do Czechosłowacji, kiedy próbował skonfrontować z Czechami nie tylko swoją wiedzę o Holubie, lecz także znajomość literatury amerykańskiej. Jak szybko się okazało, w Czechosłowacji:

5 B. Johnston, dz. cyt., s. 310-316; S. Barańczak, Introduction [w:] Spoiling Cannibals' Fun: Polish Poetry of the Last Two Decades of Communist Rule, red., tłum. S. Barańczak, C. Cavanagh, Evanston, IL 1991, s. 11, też s. XIII.

6 L. Feldman, The 10 Best Fiction Books of 2019, „Time”, 22.11.2019. 
Osoby zainteresowane literaturą wymieniały mi swoich ulubionych autorów amerykańskich. Z wielkich powieściopisarzy byli to głównie Anton Myrer, Upton Sinclair, Warren Miller, William Saroyan i Robert Ruark, z poetów Robinson Jeffers, Allen Ginsberg i Carl Sandburg. A co z Henrym Jamesem, Vladimirem Nabokovem, Donem DeLillo i Thomasem Pynchonem? Co z poetami takimi jak Wallace Stevens, Robert Lowell, Elizabeth Bishop, Thom Gunn czy Robert Frost? Nic z tego. Przed przyjazdem wyobrażałem sobie trwające do nocy gdzieś w kawiarniach Europy Środkowej namiętne dyskusje na temat wspólnych zainteresowań, ale w rezultacie nie mieliśmy wielu tematów do rozmowy, pomijając Joan Baez, Boba Dylana i Donovana. Joan Baez niespecjalnie lubiłem, a o Donovanie nigdy nie słyszałem? ${ }^{7}$.

Przesunięcia, dysproporcje i zmiany, które Quinn zaobserwował w czeskiej recepcji literatury amerykańskiej, nie stanowiły wyjątku. Jak zauważa badacz, takie przemieszczenia są nieodzownym elementem każdego transferu między kulturami, a nie tylko transferu z kultury mniejszej do większej. Co więcej, to właśnie przekłady, przejęcia i przemieszczenia pozwalają na twórcze inspiracje i rozwój literacki, o czym nie trzeba przypominać w Polsce: wiadomo jak duży wpływ na kształt literatury polskiej miały przekłady z Horacego, Baltazara Castiglione czy George'a Byrona, ale też T.S. Eliota i Ernesta Hemingwaya.

W tym miejscu docieramy do jednej z ważniejszych tez Quinna, który twierdzi, że różne obiegi zagraniczne poszczególnych prac nie są wynikiem samych tylko przypadków, mechanizmów rynkowych, indywidualnych zabiegów i problemów z przekładem. Quinn dostrzega w nich wpływy znacznie większych zjawisk i procesów. Jak pisze w swojej książce:

Kultury, jak powoli zaczynałem rozumieć, biorą sobie, co chcą i potrzebują od innych kultur, bez oglądania się na dobre maniery. Wordswortha nigdy nie uznawano za wielkiego poetę we Francji i w Niemczech, ale Byron zmienił kształt kultury europejskiej. Wciąż czekamy na przyzwoite przekłady z polskiego poety Bolesława Leśmiana, choć zmarł on osiemdziesiąt lat temu i był bez wątpienia równy innym polskim autorom, którzy w świecie anglojęzycznym zdobyli uznanie i sławę. Nawet w samej kulturze anglosaskiej reputacja niektórych autorów nie przebiła się na drugą stronę Atlantyku lub działo się to z opóźnieniem kilku dekad. W 1965 roku Czechosłowacja nie potrzebowała wyszukanego koktajlu ironii i zniuansowanych pejzaży, w których celowała Elizabeth Bishop; potrzebowała za to Allena stojącego nago na barykadzie, głoszącego prawdę niewygodną dla władzy ${ }^{8}$.

W powyższym akapicie Quinn stwierdza zatem, że kultury biorą sobie po prostu to, czego w danym momencie potrzebują - a w kolejnych rozdziałach

\footnotetext{
J. Quinn, dz. cyt., s. 11.

8 Tamże, s. 11-12.
} 
książki doprecyzowuje te potrzeby. Przykładowo w czasie zimnej wojny, w późnych latach pięćdziesiątych, poeci czescy czytali Allena Ginsberga, i czytali go w druku, jako przeciwnika amerykańskiego imperializmu - choć dla nich zarazem uosabiał on konflikt poety z władza, tak bliski pisarzom w kraju komunistycznym9. Jak z kolei pisze Quinn o Wielkiej Brytanii lat sześćdziesiątych, to właśnie wtedy, znużony anglojęzyczną poezją doświadczenia osobistego, brytyjski krytyk Al Alvarez poszukiwał tekstów otwierających się na sprawy wspólnoty - i zachwycił się czeskimi wierszami Holuba (który nauczył się wiele, adaptując poezję beatników do kultury czeskiej). Sam Alvarez nie lubił jednak Beat Generation, której polityczności nie umiał i nie chciał docenić. W rezultacie Alvarez „wyoutsourcowal” pisanie poezji „bezpiecznie” politycznej do Europy Wschodniej: wieloznaczne wiersze Holuba czytano w Wielkiej Brytanii na tle zimnej wojny i sprzeciwu wobec komunizmu. W podobnym czasie w krajach anglojęzycznych popularność zdobyła też poezja Zbigniewa Herberta, którego wiersze, podobnie jak Holuba, z pomocą Alvareza trafily do prestiżowej serii książek Penguin Modern European Poets ${ }^{10}$.

Quinn zauważa zatem, że poezja wschodnioeuropejska, w tym polska, umożliwiała krytykom i redaktorom anglojęzycznym wprowadzenie tematów politycznych, które były odległe od krytyki Stanów Zjednoczonych, a skupione na Związku Radzieckim. Jednocześnie w kolejnych dekadach polska poezja pozwalała na powrót do pytań metafizycznych i słownictwa humanizmu, do takich pojęć, jak wiara, nadzieja i duch, których anglojęzyczni poeci się wstydzili, i które zniknęły z wierszy pod wpływem innego rodzaju upolitycznienia amerykańskiej sceny literackiej i podejrzliwości wobec języka. Quinn przypomina nam jednak, że słowa te w polskiej poezji stosowano również dla celów politycznych: przeciwstawienia się ideologii komunizmu ${ }^{11}$. Clare Cavanagh opisywała z kolei, jak w latach sześćdziesiątych i później różnić się musiało podejście do języka w krajach Zachodu, których intelektualiści odkrywali właśnie maskowane w języku struktury władzy, i w Europie Wschodniej, gdzie propaganda i nowomowa były doskonale znanym składnikiem krajobrazu ${ }^{12}$.

$\mathrm{Na}$ tle zaciekawienia inną politycznością i inną liryką łatwiej zrozumieć, dlaczego głównymi przedstawicielami poezji polskiej w Ameryce są oprócz Herberta Miłosz oraz Wisława Szymborska i Adam Zagajewski. Aż tak wysokiej pozycji nie zajmuje zaś Tadeusz Różewicz ${ }^{13}$, którego późniejsze wiersze i wybory życiowe nie pasowały tak dobrze do antykomunistycznych odczytań z lat

9 Tamże, s. 86-87.

10 Tamże, s. 105-106, 109, 116, 140-141.

11 Tamże, s. 187-188. Zob. też: M. Kay, In Gratitude for All the Gifts: Seamus Heaney and Eastern Europe, Toronto 2012, s. 18-56.

12 C. Cavanagh, Lyric Poetry and Modern Politics: Russia, Poland, and the West, New HavenLondon 2009, s. 197-233.

13 J. Jarniewicz, Ttumacz między innymi. Szkice o przektadach, językach i literaturze, Wroctaw 2018, s. 326-327; B. Johnston, dz. cyt., s. 308. 
osiemdziesiątych, kiedy zainteresowanie Polską w Ameryce było największe. W tamtym czasie Różewicz nie mógł być kojarzony z opozycją wobec PRL, tak jak aktywni w USA Barańczak, Miłosz czy Zagajewski, natomiast główny tłumacz Różewicza, Adam Czerniawski, był osadzony raczej w środowisku brytyjskim $^{14}$.

Innego rodzaju - i w innej skali - przesunięcia polityczne zachodziły też niedawno w amerykańskiej recepcji książek Tokarczuk, Biegunów i Prowadź swój ptug... Z jednej strony autorka ta bywała przedstawiana w Ameryce jako osoba zaangażowana i atakowana politycznie we współczesnej Polsce, z drugiej strony była czytana w USA mniej bezpośrednio. Jej ostatnio przetłumaczoną powieść, Prowadź swój ptug..., odbierano w Polsce jako wyraźny głos w bieżących dyskusjach na temat polowań i wegetarianizmu, w Ameryce zaś ta dziejąca się gdzieś w odległej krainie historia dziwacznej starszej pani nabrała cech filozoficznej czy wręcz baśniowej refleksji nad relacjami ludzi i zwierząt, refleksji sprzeciwiającej się może polskiej polityce - ale w oddaleniu od równie gorących debat toczących się na podobne tematy w USA ${ }^{15}$.

Mimo że poświęcona poezji czeskiej książka Quinna zachęca nas do badania i interpretowania przeróżnych przemieszczeń w zagranicznym odbiorze literatury polskiej, zwłaszcza tym uwikłanym w zimnowojenne gry. Praca Quinna przypomina również o podobnych mechanizmach działających w polskiej recepcji literatury obcojęzycznej. Sztandarowym przykładem może być tutaj recepcja Szkoły Nowojorskiej pod koniec lat osiemdziesiątych, spóźniona w poezji polskiej o dwadzieścia-trzydzieści lat. O polskich o'harystach pisała szerzej Joanna Niżyńska, zwracając uwagę, jak niewiele z poetyki O’Hary rzeczywiście przejęto w tamtym czasie, jak wybiórcze było to podejście i jaką rolę odgrywało wtedy samo odniesienie do poetów z USA zamiast polskich autorów. Wybór tak rozumianej poezji amerykańskiej stanowił odpowiedź na ówczesną politykę i na dominujący w dyskursie, krępujący tym razem Polaków, leksykon poezji antykomunistycznej ${ }^{16}$.

14 Lata osiemdziesiąte: H. Stephan, Introduction: The Last Exiles [w:] Living in Translation: Polish Writers in America, red. H. Stephan, Amsterdam-New York, NY 2003, s. 8. Niewiele wierszy Różewicza trafiło do redagowanych przez Barańczaka antologii Spoiling Cannibals' Fun czy Poeta pamięta. Antologia poezji świadectwa i sprzeciwu 1944-1984, red. S. Barańczak, London 1984. Różewicz wypowiada się na temat Miłosza i Barańczaka w: K. Dedecius, T. Różewicz, Listy 1961-2013, t. 2, red. A. Lawaty, M. Zybura, Kraków 2017, s. 81-86; zob. też: C. Miłosz, The Witness of Poetry, Cambridge, MA-London 1983, s. 82.

15 Zob. np. R. Franklin, Olga Tokarczuk's Novels Against Nationalism, „The New Yorker", 5.08.2019; A. Gutterman, Horoscopes Help Solve Homicides in a Thrilling Murder Mystery, „Time”, 15.08.2019; S. Crosley, One by One, Her Neighbors Are Dying: An Elderly Polish Woman Is on the Case, "The New York Times”, 12.08.2019; R. Riederer, Olga Tokarczuk's Gripping Eco-Mystery, „The New Republic”, 10.10.2019.

16 J. Quinn, dz. cyt., s. 33; J. Niżyńska, The Impossibility of Shrugging One's Shoulders: O'Harists, O'Hara, and Post-1989 Polish Poetry, „Slavic Review”2007, nr 3. 
Podobnych pytań, o przemieszczenia pomiędzy literaturą polską i amerykańską, można by zadać o wiele więcej: o rolę tłumaczeń, przypadków i polityki w odniesieniu do innych nazwisk i innych okresów. Jeszcze ciekawsze wydają się pytania o takie transfery do innych niż anglojęzyczna kultur. Przykładowo odbiór poezji polskiej w Niemczech różni się od amerykańskiego: mniejszą rolę odgrywa w nim Miłosz, a większą Różewicz, zapewne ze względu na głębsze konsekwencje drugiej wojny światowej i wspólnego z Herbertem tłumacza, Karla Dedeciusa. A jak uzasadnić popularność Szymborskiej we Włoszech? Jerzego Harasymowicza w Ukrainie? Wydaje się niezwykle istotne, by uwzględnić w tych historiach przepływu literatury polskiej za granicę także regiony spoza Europy Zachodniej i Ameryki Północnej: Azję, Amerykę Południową, a przede wszystkim wschodnich sąsiadów Polski, kraje, których poeci często czytali utwory polskie w oryginale - lub wręcz uznawali je za część własnego dziedzictwa kulturowego (jak działo się z Adamem Mickiewiczem). Czy wiemy, jak ta mapa recepcji i wpływów wyglądała szerzej w XX wieku? Kto i dlaczego został zapamiętany? Jak wygląda ta mapa i dziś, kiedy kontakty współczesnych autorów bywają dość ożywione?

Proponowane przez Quinna ujęcie transnarodowe skupia się na literackich transferach między różnymi kulturami, nie abstrahując od wpływów poetyki, historii literatury i sytuacji politycznej na wzajemne spotkanie obu literatur. Żelazna kurtyna pod tym względem nie tylko była nieszczelna, ale także generowała dodatkowe zainteresowanie autorami z przeciwnego bloku, jednocześnie poddając ich twórczość różnym ograniczeniom i presjom. Quinn pokazuje, jaki wpływ w tamtym czasie na anglojęzyczną krytykę potrafiły mieć literatury nieanglojęzyczne, pochodzące z niewielkich krajów Europy Wschodniej.

Quinn skupia się na historiach przemieszczeń tekstów między kulturami i niezbędnych przesunięciach akcentów, których efekty widzimy dziś w postaci różnych kanonów literatury polskiej. Im bardziej odległe spojrzenie na literaturę polską, tym bardziej narzuca się to pytanie o polski kanon, niezależnie od słusznych krytyk tej kategorii. Jak zauważyła Bożena Shallcross, pisząc kiedyś o kanonie transatlantyckim i polskiej literaturze w USA, pytanie o kanon jest pytaniem o to, czego uczymy za granicą, ale też o dostępne w przekładzie dzieła i o odmienne oczekiwania kulturowe, wynikające z innego usytuowania odbiorców ${ }^{17}$.

W tym kontekście warto zadać pytanie, czy odmienne oczekiwania odbiorców zagranicznych powinny być zawsze traktowane jako przesunięcie wobec właściwych uwarunkowań lokalnych, czy miary rodzimej kultury są zawsze najbardziej adekwatnymi miarami. Czy przynajmniej niektórych autorów-emigrantów nie warto czytać na tle ich nowego środowiska, a nie rodzimej kultury? Czego możemy się nauczyć z obcojęzycznych kanonów literatury polskiej powstałych w różnych krajach? Czy świadomi wielorakich i wielostronnych

17 B. Shallcross, dz. cyt., s. 153, 156, 160-161. 
uwarunkowań transferów między kulturami, pokazanych przez Quinna, możemy na nowo powrócić do pytania o polski udział w literaturze światowej jako pewną wskazówkę do badań i interpretacji kultury polskiej? Nie chodzi tu o aspiracje do „światowości”, opisywane przez Casanovę, regulowane przez kulturowe centra Paryża czy Nowego Jorku, ale o świeże spojrzenie dostarczane przez każdą z obcych kultur, w której zaistniały polskie utwory. Być może oszczędna w środkach i zorientowana etycznie powojenna poezja z Europy Środkowo-Wschodniej rzeczywiście stanowi pewien wart zbadania fenomen zachodzących równolegle przemian formalnych wiersza, niezależnie od zimnowojennego tła, kiedy została ona wyodrębniona jako ciekawa całość ${ }^{18}$ ? Być może rację miał Miłosz, że dopiero życie na emigracji pozwala dostrzec szczególne cechy polszczyzny na tle innych języków ${ }^{19}$ ? Być może polski wkład w literaturoznawstwo i teorię krytyczną wygląda zupełnie inaczej niż przedstawiają go podręczniki, jeśli podążymy za koncepcjami, które okazały się prawdziwie wpływowe w świecie anglojęzycznym, jak „zniewolony umysł” Miłosza, „Szekspir współczesny” Jana Kotta, „teatr ubogi” Jerzego Grotowskiego czy „płynna nowoczesność" Zygmunta Baumana?

Te i tego rodzaju pytania chcielibyśmy postawić w niniejszym numerze „Kontekstów Kultury”, zastanawiając się nad wzorcami przepływu utworów polskich do innych kultur, kanonami literatury polskiej w różnych krajach oraz przydatnością wielorako rozumianej literatury światowej do analizy polskiej kultury.

\section{Bibliografia}

Barańczak S., Introduction [w:] Spoiling Cannibals' Fun: Polish Poetry of the Last Two Decades of Communist Rule, red. i tłum. S. Barańczak, C. Cavanagh, Evanston, IL 1991.

Cavanagh C., Lyric Poetry and Modern Politics: Russia, Poland, and the West, New Haven-London 2009.

Crosley S., One by One, Her Neighbors Are Dying: An Elderly Polish Woman Is on the Case, "The New York Times”, 12.08.2019.

Czapliński P., Literatura światowa i jej figury, „Teksty Drugie” 2014, nr 4.

Dedecius K., Różewicz T., Listy 1961-2013, t. 2, red. A. Lawaty, M. Zybura, Kraków 2017.

Feldman L., The 10 Best Fiction Books of 2019, „Time”, 22.11.2019.

Franklin R., Olga Tokarczuk's Novels Against Nationalism, "The New Yorker”, 5.08.2019.

18 O takiej wizji wiersza wschonioeuropejskiego jako efekcie zimnej wojny zob. J. Jarniewicz, dz. cyt., s. 299, 307, 310.

19 C. Miłosz, Język, narody, „Kultura” 1973, nr 9, s. 8 (przedruk: Ogród nauk, Paryż 1979). 
Gutterman A., Horoscopes Help Solve Homicides in a Thrilling Murder Mystery, „Time”, 15.08.2019.

Jarniewicz J., Ttumacz między innymi. Szkice o przektadach, jezzykach i literaturze, Wrocław 2018.

Johnston B., Translated from the Polish: The Fates, Feats, and Foibles of Polish Literature in English [w:] Being Poland: A New History of Polish Literature and Culture since 1918, red. T. Trojanowska, J. Niżyńska, P. Czapliński, z pomocą A. Polakowskiej, Toronto-Buffalo-London 2018.

Kay M., In Gratitude for All the Gifts: Seamus Heaney and Eastern Europe, Toronto 2012.

Miłosz C., Historia literatury polskiej, Kraków 2010.

Miłosz C., Jezyk, narody, „Kultura” 1973, nr 9.

Miłosz C., The Witness of Poetry, Cambridge, MA-London 1983.

Nasiłowska A., Pole literatury, "Teksty Drugie” 2014, nr 4.

Niżyńska J., The Impossibility of Shrugging One's Shoulders: O'Harists, O'Hara, and Post-1989 Polish Poetry, „Slavic Review” 2007, nr 3.

Poeta pamięta. Antologia poezji świadectwa i sprzeciwu 1944-1984, red. S. Barańczak, London 1984.

Postwar Polish Poetry: An Anthology, red. C. Miłosz, wyd. 3, Berkeley-Los AngelesLondon 1983.

Quinn J., Between Two Fires: Transnationalism and Cold War Poetry, Oxford 2015.

Riederer R., Olga Tokarczuk's Gripping Eco-Mystery, „The New Republic”, 10.10.2019.

Shallcross B., Requiem for a Canon? The Peculiar Case of the Transatlantic Canon [w:] Being Poland: A New History of Polish Literature and Culture since 1918, red. T. Trojanowska, J. Niżyńska, P. Czapliński, z pomocą A. Polakowskiej, Toronto-Buffalo-London 2018.

Stephan H., Introduction: The Last Exiles [w:] Living in Translation: Polish Writers in America, red. H. Stephan, Amsterdam-New York, NY 2003.

Ulicka D., Przegapiona okazja, „Teksty Drugie” 2018, nr 6. 